\title{
"WHY ARE WE TO SHUT UP THE BOOK WEEPING?"1: ELIZABETH GASKELL'S RUTH AND THE (IM)POSSIBILITY OF REDEMPTION FOR THE FALLEN WOMAN
}

\author{
“POR QUE PRECISAMOS FECHAR O LIVRO CHORANDO?": \\ RUTH, DE ELIZABETH GASKELL, E A (IM)POSSIBILIDADE DE REDENÇÃO \\ PARA A MULHER PECADORA
}

Deborah Mondadori Simionato ${ }^{2}$

\begin{abstract}
Victorian literature is filled with images of women who have sinned, but often these characters are in the background, foreshadowing the heroine's future if she is not proper and pious. Elizabeth Gaskell's Ruth, however, puts the fallen woman in its centre and calls her its heroine. This paper aims to look at the contradictions imposed on middle-class women's existence in the nineteenth century, especially concerning the figures of the Angel in the House and the fallen woman, which are essential for the analysis of Ruth and its tragic ending, in order to understand the (im)possibility of redemption for women in the Victorian period. Scholars such as Mary Poovey (1998) and Eleonore Davidoff (1995), amongst others, will provide the historical and sociological background necessary to this reading of Elizabeth Gaskell's 1835 novel Ruth.
\end{abstract}

KEYWORDS: Ruth, Elizabeth Gaskell, Angel in the House, Fallen Woman.

Resumo: A literatura vitoriana está repleta de imagens da mulher pecadora, mas frequentemente essas personagens estão no pano de fundo, agindo como premonição para o futuro da heroína caso ela não aja de maneira adequada e devota. O romance Ruth, de Elizabeth Gaskell, entretanto, coloca a mulher pecadora no centro e a chama de heroina. $O$ presente artigo pretende olhar para as contradições impostas na existência de mulheres da classe média no século XIX, especialmente nas figuras do Anjo do Lar e da mulher pecadora, essenciais para a análise de Ruth com seu fim trágico, afim de compreender a (im)possibilidade de redenção para mulheres do período vitoriano. Acadêmicos como Mary Poovey (1998) e Eleonore Davidoff (1995), entre outros, proverão o pano de fundo histórico e sociológico necessário para essa leitura do romance de 1835, Ruth, de Elizabeth Gaskell.

PALAVRAS-CHAVE: Ruth, Elizabeth Gaskell, Anjo do Lar, Mulher Pecadora.

\footnotetext{
1 This was Charlotte Brontë's response to the ending of Elizabeth Gaskell's Ruth, in a letter from 1852.

2 Doutoranda de Literaturas de Língua Inglesa do Programa de Pós-graduação em Letras da Universidade Federal do Rio Grande do Sul.
} 


\section{Introduction}

If there is a characteristic that is intrinsic and essential to the understanding of the nineteenth century, and more specifically, of Victorian times, it is contradiction. The nineteenth century was a period of progress, with the Industrial Revolution and the imperial expansion of the British Empire changing people's lives, both at home and abroad. It was also a century of culture and advancement in medicine and science, people lived longer and ate more and better, not to mention the increase in purchasing power. Alongside this wave of progress and expansion, came a moral revolution, putting aside King George IV's debauchery, and focusing on Christian values of propriety, home, and morality. As Davidoff (1995) summarizes, "doctrines of domesticity were a counterpart to what was seen as the growing incursions of the cash nexus and scientific rationality" (p. 9). Whilst men became conquerors, women became angels, the paragons of virtue and the hearth, in theory morally superior to men, in practice, overlooked and trapped into a crystallized existence.

In the midst of this century of contradictions, Elizabeth Gaskell dared to place the fallen woman in the spotlight. Literature of the time is littered with what the Victorians called fallen women, but most of them never get centre stage, and what is more, are never given the possibility of redemption. Elizabeth Gaskell's Ruth (2004), published in the first decades of Queen Victoria's reign, in 1835, tells the story of an orphan dressmaker apprentice who had no support growing up, no mother to guide her moral and spiritual growth and instruct her in womanly subjects, which meant that she was more than susceptible to the will and wickedness of ill-meaning men. "Ruth is a novel concerned with a problem - that of the unmarried mother in mid-nineteenth century society" (WRIGHT, 1995, P. 73), but Ruth is also the story of a fallen woman who never meant to sin, for she is, as the narrator insists, innocent and pure. The novel is Gaskell's bold defence of women, at the same time that it is a cautionary tale, as well as an acknowledgement of the fact that there was no recovering from such fall in that time - death is the only option, at least in nineteenth century England.

This paper intends to analyse Gaskell's novel in order to understand its tragic ending, for even when Ruth proves herself to be as good as the best of angels in the house, she cannot possibly be enough, for in 1853 there is no erasing her previous and uneducated sin. In the first section of this work, I look at Victorian society's treatment of women, especially those seen as "fallen" and how they contrast with the perfect female Angel. In the second section, I analyse Ruth's story and her path to redemption through the Victorian mindset. This will be 
achieved by analyzing the other characters in the novel and their perception of our heroine. Furthermore, the analysis will be aided by contemporary reviews and by Gaskell's defense she even went as far as prohibiting the novel in her own household - even though she intended, at a later date, to "go through it with [her daughter] Marianne" (UGLOW, 1999, p. 339). I rely on scholars such as Leonore Davidoff and Mary Poovey, amongst others, to draw a picture of women's life in early Victorian times, painting the historical and sociological background, especially concerning the figures of the Angel and the "fallen"; furthermore, Jenny Uglow's biography of Elizabeth Gaskell, A Habit of Stories (1999) is fundamental for the understanding of the author and of the novel's contemporary reception. Rachel Webster's (2012) work is also fundamental for the comprehension of how Gaskell's own religion helped her in her case for Ruth.

\title{
The Victorian Angel and the fallen woman
}

In her 1931 essay, Virginia Woolf refers to the phantom that haunts her and her work, the infamous Angel in the House. She describes this female phantom - for it is a woman, according to Woolf - as follows.

\begin{abstract}
She was intensely sympathetic. She was immensely charming. She was utterly unselfish. She excelled in the difficult arts of family life. She sacrificed herself daily. If there was chicken, she took the leg; if there was a draught she sat in it - in short she was so constituted that she never had a mind or a wish of her own, but preferred to sympathize always with the minds and wishes of others. Above all - I need not say it - she was pure ${ }^{3}$. Her purity was supposed to be her chief beauty her blushes, her great grace. In those days--the last of Queen Victoria - every house had its Angel. (WOOLF, 2009, P. 141)
\end{abstract}

It might come as a surprise that Woolf was, in 1931, preoccupied with defeating the ghost of this angelic figure who asks the impossible of women. However, considering how fundamental the image of Angel in the House, immortalized in the poetry of Coventry Patmore (1854), was in nineteenth century, it is no surprise that it was still being fought against in the $1930 \mathrm{~s}$ - and, to some extent, it is still synonymous with ideals of femininity to this day.

In order to understand the image of the Angel in the House, one must explore the provenance of the ideal angelic woman reigning over the home, and how she came to find herself there: the ideology of separate spheres. Due to the Industrial Revolution and the persistent separation of home and work that accompanied it, women's duties started to focus

\footnotetext{
${ }^{3}$ My italics.
} 
only on the household and the upbringing of children - any 'work' done by them was considered unprofessional and favouring the domestic economy; to men, however, belonged the world of business and politics - they were citizens in their own right, while women only existed in the eyes of the law as daughters, sisters and wives. Men and women were seen as completely different, and "the message that the natural difference between "manly" men and "womanly" women dictated social roles permeated mid-Victorian culture in sermons, conduct material, and popular literature" (POOVEY, 1998, p. 6). Not conforming to these differences was seen as an anomaly, constituting a problem for a society always so keen on keeping everything - and everyone - in its proper place.

This angelic woman was not only defined by her gender, but also by her class, as Langland (1995) affirms, "the feminine icon of the Angel in the House is also a middle-class ideal built explicitly on a class system of difference where political and economic differences were rewritten as differences of nature" (p. 41); there is no talking about the Angel, therefore, without remembering its middle-class origins, for it must be agreed that it would be nearly impossible to act so faultless while doing the cooking and cleaning - the figure of the Angel presumes the existence of servants who she can command into creating the perfect household. Furthermore, and of great importance for the understanding of the fallen woman, the Angel presupposes care and guidance, it comes from domesticity to later serve it.

The separation of spheres, alongside the rise of the middle classes and of puritan values, created Virginia Woolf's nemesis and paragon of the Victorian domestic ideal, the Angel in the House, the holder of virtue and morality.

Instead of being articulated upon inherited class position in the form of noblesse
oblige, virtue was increasingly articulated upon gender in the late eighteenth and
early nineteenth centuries. As the liberal discourse of rights and contracts began to
dominate representations of social, economic and political relations, in other words,
virtue was depoliticized, moralised, and associated with the domestic sphere, which
was being abstracted at the same time - both rhetorically and, to a certain extent,
materially - from the so-called public sphere of competition, self-interest, and
economic aggression. As the superintendents of the domestic sphere, (middle class)
women were represented as protecting and, increasingly, incarnating virtue.
(POOVEY, 1998, p. 10)

As Poovey observes in the passage above, the importance attributed to domesticity meant that middle-class women were esteemed as housewives, "superintendents of the domestic sphere", which provided them with a degree of self-respect and satisfaction, allowing them to perpetuate domesticity. Joan Perkin affirms that "women were proud to be efficient housekeepers, and proud to be 'the power behind the throne' exercising indirect influence through their husbands" (1993, p. 88). By being virtuous and proper housewives, 
women helped maintain the status quo that, under the guise of giving them respectability, trapped them into an impossible ideal.

The Victorian obsession with women's virtue and, more importantly, with the maintenance of such virtue, carried in itself one of the principal characteristics of the period: contradiction. The figure of the Angel implies a creature with no sexuality, and that is how women were expected to be. Victorians were obsessed with female sexuality, confirming its presence by trying to suffocate it into nonexistence - "at the heart of the explicit description of "feminine", Angelic women, superior to all physical appetite, resides the "female" sexuality that was automatically assumed to be the defining characteristic of female nature" (POOVEY, 1984, p. 19). The mere fact that women were indoctrinated to be modest and to not demonstrate their passions and desires shows there was an effort to subdue sexuality, meaning, therefore, that there was indeed sexuality to be repressed, as Mary Poovey suggests, "a modest demeanour served not only to assure the world that a woman's appetites were under control; it also indicated that female sexuality was still assertive enough to require control" (1984, p. 21). This indicates that the perception of women as pure and angelic creatures was socially constructed, and a considerable amount of energy and effort went into maintaining it. Claiming its intentions were to protect women from the evils of the outside world, middle-class society controlled women into submission and a passionless existence at least on the outside.

Therefore, the process that "created" the Angel in the House figure

culminated in a radically simplified stereotype of femininity that branded as "monstrous" any unconventional attempt to explore, develop, or express the female self, and, while it granted women considerable influence in society, this image effectively inhibited many women's ability to understand, much less to satisfy, their own desires or needs. Taught to emulate the "natural ideal", young women either repressed or sublimated other inclinations. What autonomy a woman earned was often purchased at the cost of either social ostracism or personal denial of inadmissible aspects of herself. (POOVEY, 1984, p. 35)

If the ideal femininity tries to control sexuality, its major nemesis can be no other than the fallen woman, the one who did not meet what was expected of her and allowed herself to be "ruled" by her (somehow inexistent) sexuality. The polar opposite of the idealized Madonna is the Magdalen, and Mary Poovey (1998) affirms, "the contradiction between a sexless, moralised angel and an aggressive, carnal Magdalen was therefore written into the domestic ideal as one of its constitutive characteristics" (p. 11).

Of all women who did not fit in the bourgeois ideal of domestic angel, prostitutes were the most visible and the most upsetting to respectable Victorians. [...] In Victorian drawings and illustrations, a prostitute was immediately recognisable by 
her direct gaze or uncovered head. So different was her bold demeanour from that of respectable women, privileged or poor, that a prostitute was often considered a separate species of womanhood. (PERKIN, 1993, p. 219)

According to Christianity, we are all sinners, but the prostitute, and all the other women who willingly fall "become Original Sin incarnate, the corruptible, dangerous figure, who, it can be assumed, was not predestined, and thus beyond societal and redemptive help" (WEBSTER, 2012, p. 14). There was no possibility of an in-between for middle-class women during the Victorian era, they were trapped either being a perfectly angelic and sexless creature, or an immoral prostitute. Even considerably smaller "crimes", such as becoming pregnant outside of wedlock or having an affair, were socially stigmatized as much as prostitution, for they were not in accordance with what was expected of them.

Not only were middle-class women responsible for keeping their supposedly inexistent sexuality at bay, morally educating children and supporting the men in their lives in all their endeavours, they were also held accountable for male sexuality, and once again, the "fallen" women failed in that aspect, compromising the very structure of bourgeois society. Prostitutes, then, represented more than women's weakness, but also a much uglier side of a society that had every intention of keeping its moral defects under the rug: during the nineteenth century, the number of prostitutes kept on rising, indicating not only their willingness to defy morality, but also the increasing demand that needed to be supplied. It was then named The Great Social Evil, and it was associated, as mentioned before, not only with prostitution itself, but with any deviation from what was expected from middle-class women. As Nina Auerbach expertly puts it, "the Victorian imagination isolated the fallen woman so pitilessly from a social context, preferring to imagine her as destitute and drowned prostitute or errant wife cast beyond the human community, because of her uneasy implications for wives who stayed at home" (1980, p. 33).

The myth of the fallen woman derives from Eve's biblical fall, and as Auerbach affirms, its main and most feared consequence is its "absolute transforming power" (1980, p. 34), as a woman's sin is forever imprinted on her life and on the life of those who surround her, infectious like a disease, as will be seen in Ruth. This near impossibility of redemption is explained, amongst other factors, by Victorians' constant denial of women's sexuality, meaning that if there is no passion, a woman's fall is her own conscious choice, which in turns increases the virtuous woman's responsibility and role as protector of morality and religion inside her home (WEBSTER, 2012). 
Women were pegged onto fixed categories, and the ancient split between saint and whore was a fundamental brick in the construction of Victorian ideology. Pure and angelic women were not even meant to know about prostitutes and the evils of the outside world, and were, therefore, kept in the home. With such striking differences separating women, how can the Victorian reader sympathise with Elizabeth Gaskell's Ruth?

\section{"Remember how young, and innocent, and motherless she was!"4}

Much of what we know about the Victorians and their society was learned through the literature of the time. Elizabeth Gaskell (1810-1865) lived through the early decades of the Victorian period and wrote about the condition of England and its people, taking the focus away from the provincial south and bringing it to the industrial north, where her second novel and focus of this analysis, Ruth, is set. Ruth was a bold novel, and one about which even its author felt reluctant. Gaskell was "deeply self-conscious in the writing of Ruth, and fearful too of what responses to it might be" (EASSON, 2004, p. viii), after all, it was rare, and potentially frowned upon, that fallen women be the heroines of stories. As Easson explains, "in placing such a woman not at the margins (where many such women appear in Victorian fiction) but rather at the centre of her story, Gaskell issued a challenge and then further compounded it by her treatment of Ruth's fall and of Ruth's redemption" (2004, p. ix). Despite Gaskell's reluctance, Ruth's narrator is not actively part of the action (as far as it is possible to assume without a separate analysis of the narrator), but tells it in the first person, which seems to convey Gaskell's own opinions on the matter, defending the innocence of an otherwise considered fallen woman.

Ruth tells the story of young Ruth Hilton who has lost both mother and father and is now under the responsibility of a guardian who barely knows her and therefore does not care for her. He does his duty by Ruth, settling her father's business after his death and finding her a seamstress apprenticeship with Mrs Mason - and that was the extent of his care for the broken-hearted and newly orphaned girl. Ruth is then left without home or guidance, working very late hours and having little sleep, restless for what was lost and could never again be retrieved. As Webster observes, “Gaskell uses Ruth's environment to suggest possible reasons for her susceptibility to seduction, whilst maintaining the innocence of Ruth's character and behaviour" (2012, p. 15).

\footnotetext{
${ }^{4}$ Ruth, 2004, p. 49.
} 
Throughout the novel the reader is reminded of Ruth's innocence and purity. She was "too young when her mother died to have received any cautions or words respecting the subject of a woman's life" (GASKELL, 2014, p. 39). The narrator seems to imply that it is not surprising that this pure and unprepared girl should fall victim to men such as the worldly Mr Bellingham, who at first presents himself as a friend and confidant, appealing to Ruth's loneliness and emotional neediness.

Ruth and Mr Bellingham decide to visit her former house, the only home she has even known, on a Sunday. When Bellingham proposes the foray, Ruth's instinct it to question it, as she will miss going to church. This is the first time she is led astray by his assurances - not only does he take her away from where she is meant to be, he also takes her from God, foreshadowing her sin. They stay away for too long, and on their return, are seen by the callous Mrs Mason, who washes her hands of Ruth, and casts her out, more preoccupied with the reputation of her establishment than with the poor girl.

\begin{abstract}
Mrs. Mason was careless about the circumstances of temptation into which the girls entrusted to her as apprentices were thrown, but severely intolerant if their conduct was in any degree influenced by the force of these temptations. She called this intolerance "keeping up the character of her establishment." It would have been a better and more Christian thing, if she had kept up the character of her girls by tender vigilance and maternal care ${ }^{5}$. (GASKELL, 2004, p. 48)
\end{abstract}

Had Mrs. Mason behaved more kindly towards Ruth, perhaps she would not have proceeded to the journey that serves to confirm her fall. In her defence of Ruth, Gaskell, through the narrator's voice, "attacks those who have contributed to Ruth's fall" (UGLOW, 1999, p. 325), such as Mrs Mason, and later, Mr Bradshaw. Friendless and motherless, Ruth goes away with Mr Bellingham, who convinces her of his love and persuades her to trust him, the only person who loves her - or so he claims. Even in his plea to bring her with him there is the acknowledgement of her innocence and loneliness, which is perhaps the very reason why she is such an easy prey for Bellingham.

Here you are, an orphan, with only one person to love you, poor child! - thrown off,
for no fault of yours, by the only creature on whom you have a claim, that creature a
tyrannical, inflexible woman; what is more natural (and, being natural, more right)
than that you should throw yourself upon the care of the one who loves you dearly -
who would go through fire and water for you - who would shelter you from all
harm? Unless, indeed, as I suspect, you do not care for him. If so, Ruth! if you do
not care for me, we had better part-I will leave you at once; it will be better for me
to go, if you do not care for me. (GASKELL, 2004, p. 50)

${ }^{5}$ My italics. 
Ruth represents the contradiction lived by women, as she goes with Bellingham despite feeling she should find an alternative, as it would not be proper, but because "she was little accustomed to oppose the wishes of any one - obedient and docile by nature, and unsuspicious and innocent of any harmful consequences" (GASKELL, 2004, p. 53). In being the perfectly obedient female, Ruth allows herself to be taken to her fall. When the unavoidable abandonment by Bellingham happens, encouraged by Bellingham's mother, who blames Ruth for leading her son astray, Ruth's first instinct is to try and run after him, as her love for him is true and pure, but failing that, she hopes to die and tries to drown herself. Ruth does not feel penitent for what she has done, however, for in her eyes there is nothing to repent from: she had no one apart from Bellingham, and she loved him - how could it be wrong?

Ruth, pregnant and alone, is saved by Thurstan Benson and his sister Faith. They take her to live with them as a distant relative who is recently widowed and name her Mrs Denbigh. It is her first introduction to the domesticity so associated with women. Ruth is glad of the child she is about to have, the child who is seen as purification, as her love and reverence of her child "will shut out sin" (GASKELL, 2004, p. 100). At first, Ruth had wished for a girl, "as being less likely to feel the want of a father - as being what a mother, worse than widowed could most effectually shelter" (GASKELL, 2004, p. 134), but the birth of her boy Leonard makes Ruth forget previous wishes and vow to love and protect him from $\sin$.

The Bensons do their best for Ruth, and find her deserving of a second chance, since her one mistake was not (or should not be) a reflection of her whole character, and it is through their kind and caring attitude that Gaskell confronted "head on the claims that a woman once seduced could only be retrieved (and even then perhaps doubtfully) by marriage with her seducer; or if abandoned, could not return to respectable society, and must remain a humble and excluded penitent" (EASSON, 2004, p. x). As proof that all she needed was love and care, "once Gaskell has placed Ruth into a domestic environment, she is able to dramatize the functional benefits domesticity has in restoring a fallen woman's social reputation" (WEBSTER, 2012, p. 22). Under the guidance of Mr Benson, Ruth educated herself as much as she could, "she read in the early morning the books that he marked out; she trained herself with strict perseverance to do all thoroughly; she did not attempt to acquire any foreign language, although her ambition was to learn Latin, in order to teach it to her boy" (GASKELL, 2004, p. 148). In her first year with the Bensons, Ruth learns how to "live faithfully and earnestly in the present" (p. 148) - everything she did to better herself 
was for her boy, for her biggest regret was the effect her fall could potentially have on her boy, infecting him with her sin. Domesticity changed Ruth, and yet, "there was a strange yearning kind of love for the father of the child whom she pressed to her heart, which came, and she could not bid it begone as sinful, it was so pure and natural, even when thinking of it, as in the sight of God" (GASKELL, 2004, p. 159). Once again, the narrator claims Ruth's love for Bellingham to be pure, making her sinful act more forgivable, as there was no malice on her part.

Ruth completely remakes herself to protect her son. As Mrs Denbigh, she becomes a governess to the children of one of the most rigid and moralistic men in the county - who later is exposed in his contradictions. Her love for her Leonard changes her, and she now bears the mark of domesticity, she looks and behaves like a lady, a physical change to reflect that difference inside.

\begin{abstract}
If her early brilliancy of colour was gone, a clear ivory skin, as smooth as satin, told of complete and perfect health, and was as lovely, if not so striking in effect, as the banished lilies and roses. Her hair had grown darker and deeper, in the shadow that lingered in its masses; her eyes, even if you could have guessed that they had shed bitter tears in their day, had a thoughtful, spiritual look about them, that made you wonder at their depth, and look - and look again. The increase of dignity in her face had been imparted to her form. I do not know if she had grown taller since the birth of her child, but she looked as if she had. And although she had lived in a very humble home, yet there was something about either it or her, or the people amongst whom she had been thrown during the last few years, which had so changed her, that whereas, six or seven years ago, you would have perceived that she was not altogether a lady by birth and education, yet now she might have been placed among the highest in the land, and would have been taken by the most critical judge for their equal ${ }^{6}$, although ignorant of their conventional etiquette-an ignorance which she would have acknowledged in a simple child-like way, being unconscious of any false shame. (GASKELL, 2004, p. 173)
\end{abstract}

The narrator's emphasis on Ruth's looks and how they have changed over the years she spent with the Bensons "indicates that it is the physical effects of Ruth's ordeal that have been soothed by domesticity" (WEBSTER, 2012, p. 22). Furthermore, there is a constant implication that her love and devotion to Leonard are fundamental to her reform, for "the strong bond between mother and son is also presented as evidence that the domestic space can restore" (WEBSTER, 2012, p. 22). Ruth's love for her son overshadows any childish love she might have had for Bellingham, and despite fearing that she loves her child more than she loves God, she admits to not being able to pray for a change, and this honest confession results in the narrator commenting that "unconsciously, her love for her child led her up to the love to God, to the All-knowing, who read her mind" (GASKELL, 2004, p.

\footnotetext{
${ }^{6}$ My italics.
} 
173). It is her pure and saintly connection to Leonard that "not only leads to Ruth's spiritual awakening, but protects her from the worst excesses of outside disapprobation" (WEBSTER, 2012, p. 23)

Ruth is full of contradictions, and despite the narrator's insistence on her innocence and the childlike nature of her mistake, Ruth spends the whole novel trying to atone for it, accepting suffering and whatever else is thrown at her as a form of punishment for her wrongdoing. Ruth's atonement, however, is not for society, but for God. Her chances to reform in the eyes of Victorian society are close to inexistent, but God can forgive through suffering and penitence, as Webster explains, "the narrator explicitly identifies suffering as having a spiritual benefit, with Gaskell enforcing it upon Ruth not to satisfy social expectations of punishment, but of God's law" (2012, p. 23). Suffering brings Ruth moral elevation in the eyes of God, and even, towards the end of the novel, in the eyes of the society that surrounds her, but that is not enough for her life to be clear of $\sin$.

The Bradshaws, neighbours to the Bensons, function as representatives of the middleclass Victorian society. Within their family, therefore, we find hypocrisy and contradiction coexisting with a strong moral compass. Jemima, Mr Bradshaw's eldest daughter, is the first one to find out about Ruth's past, but surprisingly, despite her ill-feelings towards Ruth at the time, she does not tell. She recognises Ruth's purity and finds her worthy of a second chance. Moreover, Jemima stands by Ruth when her true identity is discovered by Mr Bradshaw, defying her strict father in the process.

I watched her, and I watched her with my wild-beast eyes. If I had seen one paltering with duty - if I had witnessed one flickering shadow of untruth in word or action-if, more than all things, my woman's instinct had ever been conscious of the faintest speck of impurity in thought, or word, or look, my old hate would have flamed out with the flame of hell! my contempt would have turned to loathing disgust, instead of my being full of pity, and the stirrings of new-awakened love, and most true respect. Father, I have borne my witness! (GASKELL, 2004, p. 278)

More than newfound respect for the woman who has been her friend and companion for so long, but for whom she had nurtured envy and jealousy, Jemima sees her own susceptibility to wrongdoing through Ruth's, and pities her motherless friend:

\footnotetext{
"With a father and mother, and home and careful friends, I am not likely to be tempted like Ruth; but oh! Mr Benson," said she, lifting her eyes, which were full of tears, to his face, for the first time since she began to speak, "if you knew all I have been thinking and feeling this last year, you would see how I have yielded to every temptation that was able to come to me; and, seeing how I have no goodness or strength in me, and how I might just have been like Ruth, or rather, worse than she ever was, because I am more headstrong and passionate by nature, I do so thank you and love you for what you did for her!" (GASKELL, 2004, p. 299)
} 
Jemima, unlike many others of her period, recognises the advantages she has had, and how those have helped her in fighting temptation - she was brought up in a hub of domesticity, with a mother and father to teach her right from wrong, whereas Ruth was orphaned and alone from a young age. This is, once again, Gaskell's way of drawing attention to the callous treatment of women, and how such treatment does not discriminate between those who have willingly fallen in spite of their education and parental care, and those who did not know any better due to lack of guidance.

The return of $\mathrm{Mr}$ Bellingham, whose name is now $\mathrm{Mr}$ Donne ${ }^{7}$, tests Ruth's benevolence, but more than that, it threatens the peaceful life she has led so far, especially concerning Leonard and his (at this point unknown) illegitimacy. Her lack of education once again plays a part, since she agrees to meet Mr Donne because she fears he has power over her child. It is during their confrontation that the reader, at least the modern reader, comes to understand the depth of Ruth's worry about her son's future if her past mistake is found out and revealed to the world. The toll of a fallen mother on an illegitimate son is such that Ruth implies that her and Leonard's deaths are preferable to his living with the shadow of her sin.

\begin{abstract}
"To save Leonard from the shame and agony of knowing my disgrace, I would lie down and die. Oh! perhaps it would be best for him —-for me, if I might; my death would be a stingless grief- but to go back into sin would be the real cruelty to him. The errors of my youth may be washed away by my tears - it was so once when the gentle, blessed Christ was upon earth; but now, if I went into wilful guilt, as you would have me, how could I teach Leonard God's holy will? I should not mind his knowing my past sin, compared to the awful corruption it would be if he knew me living now, as you would have me, lost to all fear of God-" Her speech was broken by sobs. "Whatever may be my doom-God is just-I leave myself in His hands. I will save Leonard from evil. Evil would it be for him if I lived with you. I will let him die first!" (GASKELL, 2004, p. 247-248)
\end{abstract}

Mr Donne finally leaves, and the truth about Ruth's past comes to life, despite her best efforts to keep it a secret for Leonard's sake. The Bradshaws shun her; Leonard becomes afraid to go outside. The Bensons stand firm in their decision to support Ruth. She becomes desperate for a way to earn her keep and continue her path towards God. It is at this point that nursing the town's sick and old becomes a possibility, something that few want to do, and that once again will elevate Ruth's moral standing. "She gradually becomes known and respected among the roughest boys of the rough populace of the town" (GASKELL, 2004, p. 321), but Ruth was still dissatisfied with her progress, she did not feel herself much changed. It is then that the fever breaks amongst the poorer of the town, "that fever which is never

\footnotetext{
${ }^{7}$ His change of name is referenced as being due to an inheritance, causing him to adopt the benefactor's surname, which was fairly common at the time.
} 
utterly banished from the sad haunts of vice and misery, but lives in such darkness, like a wild beast in the recesses of his den. It had begun in the low Irish lodging-houses; but there it was so common it excited little attention" (GASKELL, 2004 p. 347). Ruth sees this as her calling - when nobody else wanted to nurse the sick with the fever, she steps in, almost certain of her impending demise as she comes into contact with the terrible fever, but certain that it is what God wants from her. Once again, she walks the path of pain and suffering in order to cleanse her soul of infection.

Ruth's work as a nurse to those who have the fever makes her even more respected in the eyes of the Eccleston community, her face had never been "so fair and gentle as it was now, when she was living in the midst of disease and woe" (GASKELL, 2004, p. 351); not only that, but her work translates into respect for Leonard too, which has always been her ultimate goal - Ruth becomes this saint-like figure, and Leonard is now able to walk the town erect and proud of his mother.

After a long period of incessantly nursing the sick, Ruth returns home, and is recognised for her services to the town, but duty soon calls her back to the sickroom, when Mr Donne falls sick and she feels it is she who should go to him - for the second time she nurses him, and as Wright affirms, "his [first] recovery is the beginning of her trials; his second recovery is the beginning of her peace" $(1995$, p. 94). This is her final penitence, the one from which she will not recover, as Mr Donne infects her for the second time, this time with the fever that she cannot defeat. Ruth's status is elevated to that of a martyr-like figure, and for that she has to die, and in her death, she gains the approval of even her most severe critics, bringing tears to harsh Mr Bradshaw's eyes.

\section{Conclusion}

Ruth is a Magdalene in a world that only ever accepts Madonnas. Many have claimed the difficulty the modern reader finds in understanding why she has to die, especially after all the penitent year, but such was the possibility (or lack thereof) for women who had sinned in the nineteenth century, as Jenny Uglow affirms "Ruth had to die, if only to wring a final tear of sympathy from readers and hardened critics. The sacrificial altar is that of literary as well as of moral convention: madness or death is the fate of all fallen women" (1999, p. 337).

Despite Ruth's ending, which in many ways confirms her status as a fallen woman whose only redemption is possible through death, Gaskell finds a way of criticising society 
through shedding light on how this same society that crucifies her protagonist is the one who "made" her into who she is and facilitated her fall.

\begin{abstract}
In order to defend the rights of the seduced girl and the illegitimate child, Gaskell attacks those who have contributed to Ruth's fall, denying her 'tender vigilance and maternal care' - her careless father, her neglectful guardian, her employer Mrs Mason, her lover Bellingham - and those who condemn her without thought, like Mrs Bellingham and Mr Bradshaw. These are the people in the dock. Bradshaw in particular is savagely exposed, and in this portrait, one feels something rare in Gaskell's writing, an active, angry dislike. This domestic bully and sanctimonious public figure is the kind of man who would not only damn Ruth in real life, but actually burn the book that told her tale. (UGLOW, 1999, p. 325)
\end{abstract}

Ruth is a novel of its time, dealing with two extremely relevant subjects for the age: what happens to the fallen woman - especially when she is not a prostitute - and to her illegitimate son. It reinforces the importance of domesticity for women, so praised in the nineteenth century, and criticises a society that, despite its claims to religion and the high moral ground, looks down on women who have not had the advantages necessary to avoid a sinful life. Had the Bensons not taken Ruth in, her fate would almost certainly have been prostitution, driving her further away from a godly redemption. Furthermore, in Ruth, Gaskell presses forward her Unitarian beliefs, mainly the negation of the idea of Original Sin and the belief that "the human mind and soul were not innately sinful, but instead were born with an immense potential for growth. Unitarians considered the environment as fundamentally responsible for shaping the individual" (WEBSTER, 2012, p. 15). Gaskell's Unitarianism helps her weave her plot and construct her character, at the same time that it sustains her criticism of her own society.

Charlotte Brontë, in a letter to Mrs Gaskell, was clear about her disapproval of the ending of novel, and yet Gaskell knew it was the only possible fate for a fallen woman who repented - had Ruth not died, would Charlotte Brontë have been able to see her with the kindness her death allowed? "The idea of salvation through death is as fundamental to Christian thought as Christ's own sacrifice" (WRIGHT, 1995, p. 91) - God might have forgiven Ruth before her death, but society would never accept her fully, regardless of her constant sacrifices. Gaskell did not even trust her readers to look kindly on Ruth, in spite of the narrator stressing her innocence and purity at every turn - "she knew [...] that in most readers' opinions the blame would lie with Ruth herself' (UGLOW, 1999, p. 325).

Gaskell had bravely set out to challenge the Victorian myth of fallenness, choosing to depict a heroine free of Original Sin, restoring her into the domestic setting where female friendships were prioritised and sexuality was affirmed. And yet there is a sense that Gaskell continued to be frustrated with the limitations of Victorian culture, as witnessed in her unease of how Ruth would be received. Unable to comprehend 
the full restoration of a fallen woman in her own reality, in a fit of disappointment, she handed Ruth over to the Unitarian security of redemption in death. (WEBSTER, 2012, p. 25)

Victorian women were subject to numerous constraints, and none more important than that of repressed sexuality. More than anything, Ruth's sin was to desire where no desire was allowed, even if pure and loving. Victorian society did not accept female desire, especially when it presented itself as natural, felt by an innocent girl. Had Ruth lived, she would have reaped the benefits of her sacrifice, being valued by the inhabitants of Eccleston and seeing her son as an accepted member of the community. She would never have married or be bared children again, however, as there is no forgetting her sin, even if it looks, for all intents and purposes, forgiven. Death, then, is the only alternative for Ruth, and for many other fallen women, as it is the ultimate and unquestionable sacrifice - not even $\mathrm{Mr}$ Bradshaw can contest it.

\section{REFERENCES}

AUERBACH, Nina. "The rise of the fallen woman". Nineteenth-Century Fiction, v. 35, n. 1, pp. 29-52, June 1980.

DAVIDOFF, Leonore. Worlds between: historical perspectives on gender and class. Oxford: Blackwell Publishers, 1995.

EASSON, Angus. "Introduction". Ruth. London: Penguin, 2004.

GASKELL, Elizabeth. Ruth. London: Penguin, 2004.

HYATT, Valerie Ann. A plea for sympathy and understanding in the portrayal of motherless daughters in Elizabeth Gaskell's fiction. Dissertação (Mestrado em Literature Inglesa). Iowa State University, 2006.

JAFFE, Audrey. "Infection and feeling in Mrs Gaskell's Ruth". Victorian Web. http://www.victorianweb.org/authors/gaskell/jaffe3.html. Web. 14 July 2018.

LANGLAND, Elizabeth. Nobody's angels: middle-Class women and domestic ideology in Victorian culture. Ithaca: Cornell University Press, 1995.

LANGRIDGE, Rosemary. "The tearful gaze in Elizabeth Gaskell's Ruth: Crying, Watching and Nursing". Journal of International Women's Studies, v. 12, n. 2, pp. 47-60. March 2011.

MALCOLM, Elizabeth. "Ruth". Victorian Web. http://www.victorianweb.org/authors/gaskell/malcolm/4.html. Web. 14 July 2018.

McBEE, Comanchette Rene. Revoking Victorian silences: redemption of fallen women through speech in Elizabeth Gaskell's fiction. Dissertação (Mestrado em Literature Inglesa). Iowa State University, 2012.

MITCHELL, Sally. The fallen angel: chastity, class and women's reading 1835-1880. Bowling Green: Bowling Green University Press, 1981.

PATMORE, Coventry. The angel in the house. CreateSpace Independent Publishing Platform, 2013.

PERKIN, Joan. Victorian women. London: John Murray, 1993.

POOVEY, Mary. The proper lady and the woman writer. Chicago: University of Chicago Press, 1984. 
POOVEY, Mary. Uneven developments: the ideological work of gender in mid-Victorian England. Chicago: University of Chicago Press, 1998.

UGLOW, Jenny. Elizabeth Gaskell: a habit of stories. London: Faber and Faber, 1999.

WEBSTER, Rachel. "I think I must be an improper woman without knowing it': fallenness and Unitarianism in Elizabeth Gaskell's Ruth". Victorian Network, v. 4, n. 2, pp. 10-28. Winter 2012.

WISE, T.J., and SYMINGTON, J.A., ed., The Brontës: their lives, friendships and correspondence, 4 vols. Oxford: Blackwell, 1980,

WOOLF, Virginia. Selected essays. Oxford: Oxford University Press, 1999.

Recebido em 06/08/2018. Aceito em 24/10/2018. 